expanded. Finance ministers everywhere are no doubt glooming at the steady improvement of therapies that prolong the lives of cancer or AIDS patients, for example. What they will have to recognize is that there is nothing sacrosanct about present proportions of GDP spent on medicine and that, a few decades from now, they will seem small. Then the question of how to meet the cost will re-emerge.

\section{Aquarium Fights Back}

The New England Aquarium, acused by animal rights groups of violating regulations, is countersuing for defamation.

For years, the New England Aquarium in Boston, known for coming to the rescue of beached whales, dolphins and seals, has been fighting legal assaults from animal rights groups who charge aquarium scientists with illegally taking animals from the sea. The most noted dispute centers on a dolphin named Kama that was transferred four years ago from the aquarium to a US Navy base for sonar research.

The animal rights groups say the transfer was illegal. Under the US Marine Mammal Protection Act, an aquarium must get a government permit to keep (or transfer) any animal taken from the wild. Because the aquarium had no permit, it had no right to send Kama to the Navy where, the groups claimed, Kama would be turned into a "lethal dolphin torpedo". The transfer was especially aggregious, they contend in a flier designed as a fund-raiser for their groups, poor Kama was "violently removed from his family group and put into captivity at the New England Aquarium".

Not so, say aquarium scientists. To begin with, Kama was born not in some romantic natural spot in the ocean near Bermuda; he was born at Sea World, an aquarium in San Diego. (The rights groups dismiss this fact as a "minor mistake".) Further, aquarium scientists insist that the Navy promised not to use Kama for other than sonar studies and report that an independent oversight panel confirms this.

What finally pushed the aquarium over the edge? What drove a conservative institution to risk a countersuit in court, with all the legal costs entailed? In June three animal rights filed a suit against the aquarium alleging that it has failed to obtain necessary permits before making any attempts to rescue beached mammals. Obtaining such permits could take up to six months, aquarium officials state, and the delay would "guarantee certain death to these animals".

Arguing that the animal groups real agenda is to put all aquariums out of business, the New England Aquarium now threatens to go to court to recover $\$ 5$ million in damages for what it says are false and defamatory statements against it. The aquarium alleges that the misleading stories about Kama have caused some of its patrons to drop their contributions, while the coffers of the rights groups have increased.
It is high time that institutions under attack from extremist animal rights groups fight back. A dozen or so aquariums in the United States are expected to file amicus or "friend of the court" briefs on behalf of the New England Aquarium, which is a good sign of solidarity. It is also proper that the aquariums have decided to fight harassment with harassment. Should the New England Aquarium win its case (and \$5 million), animal rights extremists would get a deserved dose of their own medicine. As the aquarium points out, it costs millions to fight lawsuits in the courts and scientists are tired of seeing resources go to lawyers that could otherwise go to research.

Even more important, the aquariums should use this occasion to engage in a public debate on the real issues. No sensible person believes that the animal rights groups are really concerned about permits. They want to change laws that allow aquariums to keep and display sentient mammals under any circumstances. Their argument that human beings have no business keeping intelligent sea mammals in captivity is not without merit and derseves to be debated..

But, as the New England Aquarium points out, a legitimate argument can be made in favor of displaying sea mammals on educational grounds. The aquarium argues, for instance, that the one million people who visit every year $(150,000$ of them are school children) benefit greatly from seeing mammals in the aquarium's pools and that, by extension, mammals in the wild benefit too. Aquarium scientists want public support (both financial and moral) for studies of marine habitats and the preservation of populations of whales, penguins and other mammals. They are particularly interested at present in preserving the endangered North Atlantic right whale which may be dying off as a result of inbreeding.

How, scientists ask, can the general public understand the importance of the research at the New England Aquarium (and others) if people never have an opportunity to see a whale or a dolphin or a seal up close? Speaking of inner city children, the aquarium director put it vividly in an interview when he said, "The only animals they see are rats, pigeons, cats and dogs. If that's all you see, why should you be interested in conservation?" If they are taught that scientists steal cute dolphins from their homes and turn them over to the military, children surely will not think well of science.

It is no exaggeration to say that, in this and other disputes between the scientific community and animal rights groups, the issue goes to the very heart of the value of research on animals in all its many forms. Particularly in the aquarium's case, this is not a dispute over nuances. It is about the ethics of using animals for human benefit. It is imperative that animals be treated humanely, but is also reasonable that researchers themselves be treated humanely - that is, not subject to years of petty harassment that is merely a ploy for avoiding debate on the real issue. The aquarium is right to go to court. 